\title{
The Liberation Route Europe: Challenges of Exhibiting Multinational Perspectives
}

\author{
Jory Brentjens and Wiel Lenders
}

In February 2014 the traveling exhibition Routes of Liberation: European Legacies of the Second World War was launched at the European Parliament in Brussels. The exhibition, which considered the origins, course and complex legacies of World War II was an initiative of the Liberation Route Europe Foundation (LREF) in collaboration with a consortium of leading World War II museums and other partners. ${ }^{1}$ The opening of the exhibition marked the end of a period of six months of close collaboration between historians, projectmanagers and designers from five European countries: Great Britain, France, the Netherlands, Germany and Poland. A collaboration that, due to the still sensitive subject matter of World War II, was challenging and knew quite a few problems.

We live in a time in which Europe is no longer a vague concept but a very concrete political entity, if one that is subject to ongoing challenges. However, it appears that there is still a lot of work to be done to come to a shared understanding of the legacies and meanings of World War II that takes into account the viewpoints from a variety of countries rather than just one's own. Especially by the general public in specific European countries, the history of World War II is often perceived as one singular story. The fact that there are several histories of World War II, with each country having a distinct way of looking at the war, is lost on the majority of Europeans and herein lies the main challenge for the Liberation Route Europe.

One of the unique features of Routes of Liberation is that it is the first exhibition on World War II to employ a multi-perspective approach: it is organized on a broad European scale, with input from five countries. The national narratives of Great Britain, France, the Netherlands, Germany and Poland are brought together in one exhibition and made to challenge one another. The results are often interesting but also give rise to a unique set of problems. The inherent problem with a transnational European approach to the history of World War II and its aftermath is that each country is still very much bound

1 www.routesofliberation.com/theexhibition. Accessed on September 8, 2015.

(C) JORY BRENTJENS AND WIEL LENDERS, 2018 | DOI 10.1163/9789004292017_019

This is an open access chapter distributed under the terms of the prevailing CC-BY-NC License at the time of publication. 
by its own national paradigm. This paradigm, though it has shifted in the postwar period, has developed in different directions in each country. The broader public, as well as the historians working on the Routes of Liberation project, are still influenced by these paradigms, which led to many discussions in the process of creating the exhibition. In this article, the national narratives that have developed in the participating countries will be discussed before going into the process of the creation of Routes of Liberation and the problems that occurred along the way. At the end of the article, we will analyze the transnational and multi-perspective approach in order to evaluate to what extent the Routes of Liberation exhibition has been able to shape a transnational European perspective on World War II.

\section{National Narratives World War I I}

The moment World War II had ended, the writing of its history began. In the years immediately after 1945, the history of the war in Western Europe was interwoven with already existing national, political and religious discourses. In Eastern Europe, in the countries under Soviet dominion, the collective memory was heavily influenced by a nationalistic and communistic ideology laid down from above (Vree and Laarse 26). Despite these general trends, each country still wrote its history in accordance with its own national wartime experiences which led to several distinct histories. There were of course large similarities between these histories but to this day each country has tended to focus on the themes that were/are most relevant to it. It is only in the last few decades that a movement towards convergence of these separate histories can be observed in the narratives of World War II (Vree and Laarse 15).

\section{Great Britain: Heroism on the Battlefield}

Great Britain was one of the major Allied powers and played a key role in the final defeat of Nazi Germany. After years of appeasement Britain declared war on Germany on 3 September 1939 after the Nazi invasion of Poland. After eight months of relative quiet, the Allied forces clashed with the German army in May 1940. The French army held out for several weeks but eventually had to capitulate to the superior German forces, leaving Britain alone in facing Nazi Germany. The British endured the Blitz and fought the Axis forces in Africa and Italy before landing in France in June 1944. After some of the heaviest fighting 
of the war in Normandy, the Allied armies continued their advance towards Germany until the Nazis capitulated in May 1945.

One of the most distinguishing features of Great Britain's experience of WWII is that the country was never occupied by German forces (with the exception of the Channel Islands). This "lack" of occupation, which sets Great Britain apart from other European countries, made British historiography differ from that of the rest of Europe. Although the country was heavily bombed during the Blitz and its survival was uncertain when the German U-boats scored large successes, it never had to endure the repressive Nazi rule. The absence of occupation also meant the absence of a resistance movement. These two elements, oppression and resistance, would become central themes in the historiography of countries that were occupied, like France and the Netherlands, in the first decades after the war (Vree and Laarse 7 and $32-33$ ). Since these themes were nonexistent in the British experience of the war, British historiographers mainly focused on other aspects of the war. One of the key themes that arose in Britain was that of heroism on the battlefield. As a consequence, the victorious campaigns in North Africa, Normandy and Northwest Europe took center stage in war history alongside stories of the individual bravery of the ordinary soldier. This approach has reduced the story of World War II to a series of British victories and has left little room for historical complexity. Slowly, however, this image has been shifting under the influence of more nuanced, multiperspective and transnational approaches of academic historians (Liberation Route Europe Foundation 11).

\section{France: Oppression and Resistance}

France was invaded by the German army in May 1940 and capitulated after six weeks of heavy fighting. The country was to face four years of Nazi occupation during which the French population reacted in a variety of ways to German rule. In the South of France a collaborationist state was set up under Marshal Pétain that closely collaborated with the occupying authorities and assisted in the deportation of a large number of French Jews. On the other side of the spectrum, the French formed a large underground resistance movement, which saw its most active phase in 1944 when it helped to prepare for the Allied invasion (4). In the summer of 1944, France became the setting of some of the heaviest fighting seen on the Western Front as the German forces clung tenaciously to their positions in Normandy. At the end of the war, France was regarded as one of the victorious powers and gained a seat at the table in shaping the postwar future of Europe. 
The French perception of World War II was marked by a very different approach than the one seen in Britain. The French could not look back on a war that was skillfully fought. The defeat of 1940 was a painful memory as was the large-scale collaboration of Vichy France. These historical events were quickly pushed out of the national collective memory in the first years after the war. Instead, French historians focused on the themes of oppression and resistance. This image of a country that defied a brutal occupation only began to shift from the late sixties onwards (Vree and Laarse 32-33). From this time on, more sensitive topics such as the fate of the French Jews, French collaboration with Nazi Germany, and the defeat of 1940 have gradually made their way into French collective memory offering a more differentiated view on history.

\section{The Netherlands: History in Black and White}

The Dutch collective memory of and historical perspective on the war show many similarities with the French. Like France, the Netherlands could not look back on a successful and professionally organized defense against the German invasion. The country capitulated on 15 May 1940 after only five days of fighting during which the Dutch army was completely overwhelmed. Instead of bravery in battle, oppression and resistance became the dominant themes in Dutch collective memory and history: the image of Queen Wilhelmina in London defying the Nazis and stories of an active large-scale resistance movement were juxtaposed with events such as the bombing of Rotterdam and the large-scale famine that took place in the winter of 1944-1945, known by the Dutch as the "Hongerwinter." There was hardly any room for nuance and the fact that the majority of the Dutch had taken a stance of accommodation was forgotten (Somers 122).

Another key feature of Dutch historiography was the tendency to view society as being split into right and wrong. This polarized view was heavily influenced by the work of Loe de Jong, who became one of the most important Dutch chroniclers of World War II (see Heijden 16). A black and white history was created in which people had either been members of the resistance or collaborators (see Ginkel 730). For the large grey area that existed between these opposites there was hardly any attention. This idea persisted for a long time and until the late 196os resistance fighters and soldiers would remain the focal point of the public's attention (Ginkel 726 ). From the late 1960 on and early 1970s, a more pluralistic image emerged as different groups started to emphasize their own history. The one "grand narrative" of the war 
shifted from the theme of sacrifice to oppression (Ginkel $506-7$ ). The focus now shifted to groups of people that had suffered during the war instead of lingering on resistance members or soldiers who sacrificed their lives. Other groups started to claim their own place in the history of the war and a hierarchy of victimhood was established (Ginkel 509). In this hierarchy the persecution of the Jews assumed a central place but also people that were not directly influenced by the war such as the children and grandchildren of the victims (Ginkel 509). It is also from this time on that the Holocaust gained its central place in the Dutch collective memory and other painful themes received more attention (487). From the 1990 os onwards, the "grey" area that existed between the two extremes of right and wrong was given much more attention. This development changed the Dutch view on wwil history from one of black and white into a much more nuanced one that allows for more shades of grey.

\section{Poland: Between Two Totalitarian Regimes}

Poland is arguably one of the countries that suffered most during the war. In September 1939, the German and Soviet armies invaded the country. Both the Nazis and the Soviets established ruthless occupational regimes that were responsible for the murder of tens of thousands of Polish citizens as early as 1939-1940 (Liberation Route Europe Foundation 7). Furthermore, Poland was to become the primary scene of the Holocaust with some of the most infamous Nazi concentration- and extermination camps being located there. Polish forces fought on all fronts during the war, from Africa, Italy, France to the rest of Northwest Europe but also alongside the Red Army on the Eastern Front. Poland had one of the largest and most sophisticated resistance organizations of the war. The Polish underground had a parliament, schools and courts as well as a very large military branch in the form of the Home Army, which made an unsuccessful attempt to liberate the Polish capital in 1944. Despite all the fighting and suffering the Poles went through during the war, the outcome was very disappointing. Nominally, Poland was one of the victorious countries, but it lost its freedom and independence when it came under Soviet rule at the end of the war.

In the years after World War II, Polish public memory was substantially shaped by the Communist Party line. National and heroic memory was promoted and it became impossible to discuss the crimes committed by the Soviet Union. The communist government supported a history in which Nazi Germany was portrayed as the only enemy of Poland and which left 
out the role that the Soviet-Union had played in the invasion of Poland in 1939 .

Events such as the Warsaw uprising of 1944 that showed the desire of the Poles to free themselves and become an independent state once again did not find a place in Polish history books until the end of the 1980 os (Vree and Laarse, 26). In Polish historiography of wwII the Jews were at first not regarded as a special group of victims. The persecution of the Jews was seen as just one element of the broader suffering that had befallen Poland. This image started to change from the mid 1950s onward during the period of de-Stalinization but still the Soviet narrative remained dominant. Only after the fall of the Soviet Union in the early 199os did a Polish national narrative on World War II that was free from Soviet interference begin to take shape.

As a result of this, an emancipatory feeling has existed among Polish historians since the early 199os. They-rightfully-feel that in the decades following the war the historiography of Poland was not free of Soviet interference and are determined to correct this. In the years immediately after the fall of the communist regime this even led to some ultranationalist views on history in which former Nazis where praised for fighting the Soviet Union (38). These nationalistic views were quickly abandoned in favor of a more nuanced approach as Poland sought to connect with the European Union (38).

Nevertheless, the Polish attitude towards World War II still differs from that of other European countries and continues to have immediate relevance to the contemporary political situation. It was not until 1989-199o that they could fully face up to the real nature of the war. Here, we can find one of the challenges of the multi-perspectival approach. Perhaps as a consequence of this temporal lag, the Polish attitude towards the history of the war is more unforgiving than, for instance, the British or the Dutch. This attitude was reflected in discussions and had a direct influence on the exhibition as will be seen later on.

\section{Germany: Facing the Facts}

Nazi Germany was the country that started the war and was responsible for the Holocaust. It was also the country that lost the war as well as the only country in modern history to see a war to its absolute end, choosing not to capitulate when all hope for a positive outcome of the war was lost but instead to keep on fighting (See Bessel 385). 
In the years directly following the war, most German citizens did not consider the arrival of the Allied armies as a liberation from the National Socialist regime, as Richard von Weizsäcker suggested they should in a speech in 1985 , but rather saw it as a bitter defeat (Liberation Route Europe Foundation 9). The country lay in ruins and was divided between the Western Allies and the Soviet Union. This division between East and West is reflected in the German historiography. In the German Democratic Republic (GDR) the collective memory was heavily influenced by the Soviet Union (like in Poland), while in the Federal Republic of Germany (FRG) the population began to see itself as an innocent victim of the Nazi regime (LREF 12).

When the Allied and Soviet forces took over Germany, they confronted the German population with the crimes that had been committed during the war, including the treatment of the Jews in the camps. Faced by these overwhelming charges the German population pushed the history of the Holocaust and other war crimes to the back of their minds and focused on themselves and the suffering they underwent during the war (Bessel 388). The German population was still not ready to face the facts and emerged from the World War II with what Richard Bessel called a strong sense of victimhood, focusing on the destruction wrought on German cities and the large number of German war casualties (Bessel 396). This view started to shift in the 1960s when a new generation of Germans began to ask penetrating questions about their past and protested against the fact that former National Socialists were still in positions of power in West Germany (Bessel 396). From the 1980s onwards, the collective memory in Germany became more pluralistic, concrete and individualistic and World War II became an important point of moral reference (Bessel 228-9).

\section{Differences and Similarities}

There are significant parallels as well as large differences between European countries in terms of how the history of World War II was written and collective memories were formed after the war. Although the historiography and collective memory have developed along similar lines in various countries, they are still mostly nationally confined. With the Liberation Route European Foundation and the Routes of Liberation exhibition we try, for the first time, to bring together these differing yet converging European national views into a multi-perspective whole and see what can be learned from the process. 


\section{Challenges of the Multi-Perspectival Approach}

The varying national outlooks on history played an important role in the sometimes fierce discussions about the content of the Routes of Liberation exposition. Here, some of the most sensitive topics in the history of World War II were addressed, often with interesting results. To gain a better understanding of these results it is first important to know a bit more about the way the Routes of Liberation exposition is designed. The exhibition consists of three parts. The first part deals with the events leading up to World War II, such as the Versailles peace treaty, the Russian Revolution and the Munich agreements. It does so by using fictional headlines from contemporaneous newspapers for instance: Bolsheviks seize power in Russian empire or War Erupts! The second part, the core part of the exhibition, consists of twelve themes and sixteen biographies. The themes range from bombing to fighting, resistance, Holocaust, destruction, collaboration, and so on. Each theme is introduced by a short text that was agreed upon by all the historians involved and illustrated by five images that were supplied by the parties involved. The sixteen biographies are distributed over the five countries and provide information about a broad range of subjects and persons from all the countries involved. The third part of the exhibition focuses on postwar developments, such as the division between Eastern and Western Europe, the downfall of the Soviet Union, and the beginning of a strong European collaboration.

Discussions about the content of the exhibition were often quite intense. For the theme of "resistance," for example, the German partners supplied an image of the aftermath of the failed assassination attempt on Adolf Hitler by German army officers on 20 July 1944. The image raised the question if this act could or should be classified as resistance. Another example concerned the image that the Polish partners supplied for the theme of "collaboration" which depicted Ukrainian volunteers of the Waffen-ss instead of Polish collaborators. For the theme of "terror and extermination" the Dutch put forward a photo of Dutch prisoners in a Japanese camp in the Dutch East Indies. The brutal campaign of the Netherlands to reconquer its former colony, however, could just as easily have been placed in this category. When it turned out that there was one biography too many for an equal distribution between all countries, the French courteously offered to drop one of their biographies: the one that told the story of a French collaborator. The other partners protested and a different biography was dropped. A final example concerned the biography of the German Field Marshall Walter Model, which contained a quote by Model labeling himself a hero of National Socialism. The Polish partners 
protested that they would not take part in an exposition that depicted German generals as heroes. After prolonged discussion the quote was dropped. The examples above form a good illustration of how the various partners' wartime experiences and historiographies continue to influence their outlook on the past. The heated debates that the representation of war from varying national perspectives is likely to trigger continued in the letters that visitors of Routes of Liberation sent to criticize the choice of certain texts, images, themes and biographies.

Looking toward the future, we believe it would be good to deepen the current collaboration and add more countries to the list of participating partners. Italy would make an interesting addition since it would allow for a comparison between Germany and another Axis country, and provide an opportunity to critically consider the differences between two totalitarian states. The perspective from the Balkans and other Eastern European countries such as the Ukraine or the Baltic States would also from a good addition since at the moment the Eastern European perspective is only represented by Poland. Then there is the special case of Russia. An overview of the European history of World War II cannot be truly complete without taking into account the Russian perspective. Unfortunately, with political tensions between the East and the West currently on the rise, collaboration with Russia seems unlikely. Furthermore, the Russian culture of commemoration and the nation's collective memory differ greatly from that of the Western European countries and Poland, rendering potential future collaborations particularly challenging.

\section{A European Perspective on War?}

Behind all of these efforts lies the question: why should we work on a European perspective on war? Why is it so important for us to be critical of our national narratives, to look across borders, and to take the histories of other countries into account? Why does it not suffice to focus on those historical themes that are most relevant to our own wartime experiences? The answer to these questions is not a straightforward one. First of all, there is nothing inherently wrong with the investigation of national and regional histories. In fact, it would be strange to stop doing so. We focus on the history that is closest at hand and that has shaped our collective memory the most. Even apart from the question whether it is possible to look at history without the influence of our national paradigm, it would not be a good idea to abandon our national perspectives for a European one. The true value of the LREF and a project like the Routes 
of Liberation Exhibition can be found in the way the foundation and exhibition serve as a platform for transnational discussion and debate. By bringing together the national histories of multiple European countries, a broader context is created in which one's own national history can be better understood. It also forces us to look at our own history from a different perspective, which can bring some painful but very valuable realizations to light that in the future might lead us to change our national narratives.

To illustrate how bringing the perspectives of five European countries together may lead to a better understanding of history, let us finally consider the example of the geographical map that is included at the end of the exhibition. This map shows the advance of the Allied and Soviet forces across Europe and is very revealing in its simplicity: in Western Europe the Western Allied forces and especially Britain and the United States are seen as the two major powers that brought down Nazi Germany. Since English-speaking soldiers were responsible for the liberation of this part of Europe, and since postwar relations between East and West left little room for appreciation of the Soviet forces, this is perhaps logical. However, the simple fact which the map also displays is that the war was largely won in the East. During several years of brutal fighting, the Red Army managed to survive the initial crippling blows of the Nazi invasion and gradually ground down the German army until it was finally and relentlessly pushed back. When the Allied armies advanced out of Normandy in August 1944, the Red Army stood at the gates of Warsaw just 6 oo kilometers from Berlin. These simple facts are often overlooked but have the power to dramatically alter the way we view the roles that the Allies and the Soviet Union played in defeating Nazi Germany. Here we see the value of having Poland as a partner country of the LREF: its participation opens the door to historical insights from Eastern Europe which are still not commonly taken note of among Western Europeans.

All in all, the Routes of Liberation exhibition brings together the histories of several nations in a comparative mode. The goal is not to determine which country suffered the most, had the highest number of victims, collaborated the most or had the most active resistance network. Instead, the goal is to gain a broader contextual understanding of our own histories. Selective memory of the war in individual nation states demands an international response. There is still much to be learned from each other and with the future plans of the Liberation Route Europe Foundation this hopefully will be achieved. ${ }^{2}$

2 The LREF is currently involved in several projects. Italy and Luxembourg are scheduled to join the foundation in the near future. 


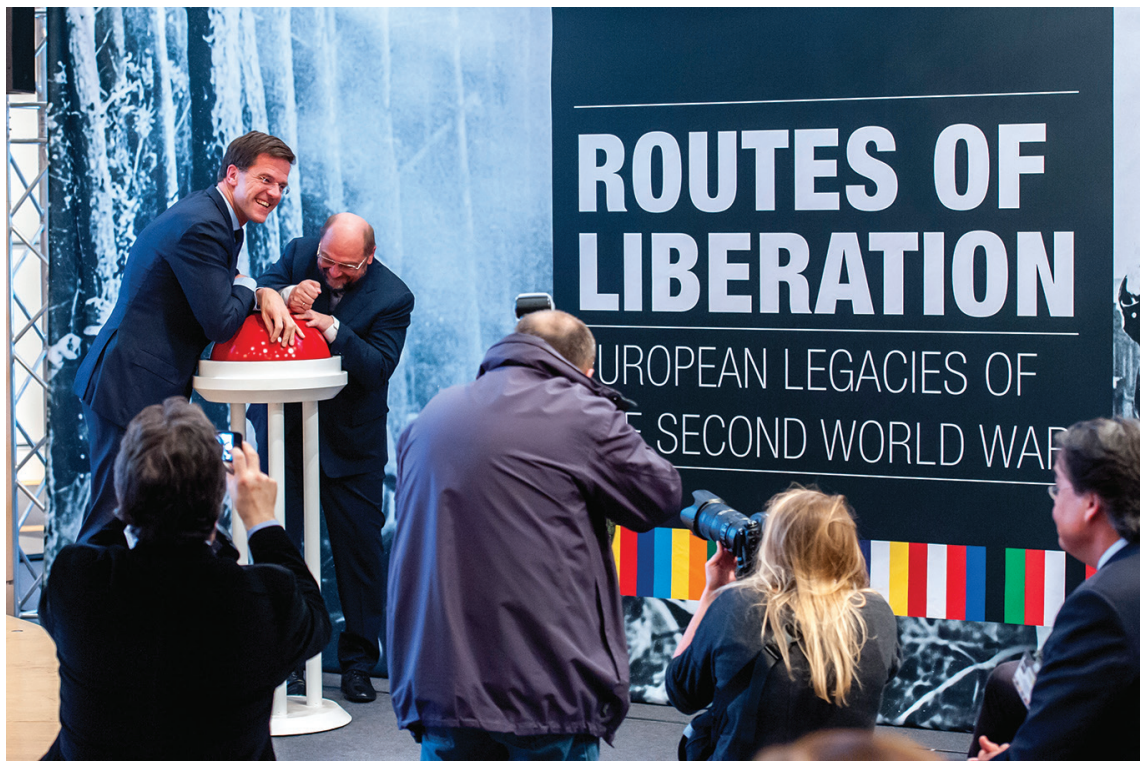

FIGURE 1 The Dutch prime minister Mark Rutte and president of the European parliament Martin Schulz open the Routes of Liberation exhibition in Brussels. () Stichting Liberation Route Europe.

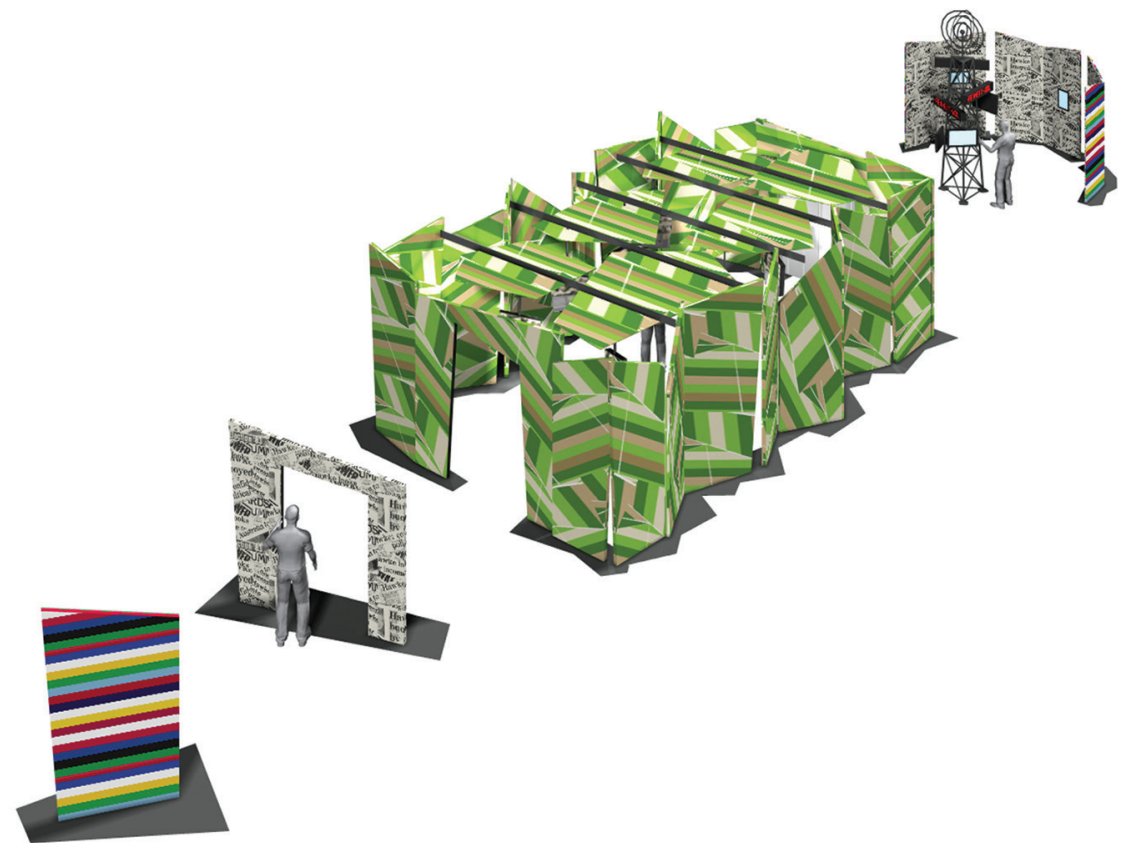

FIGURE 2 Early design of the Routes of Liberation exhibition. (C) Stichting Liberation Route Europe. 


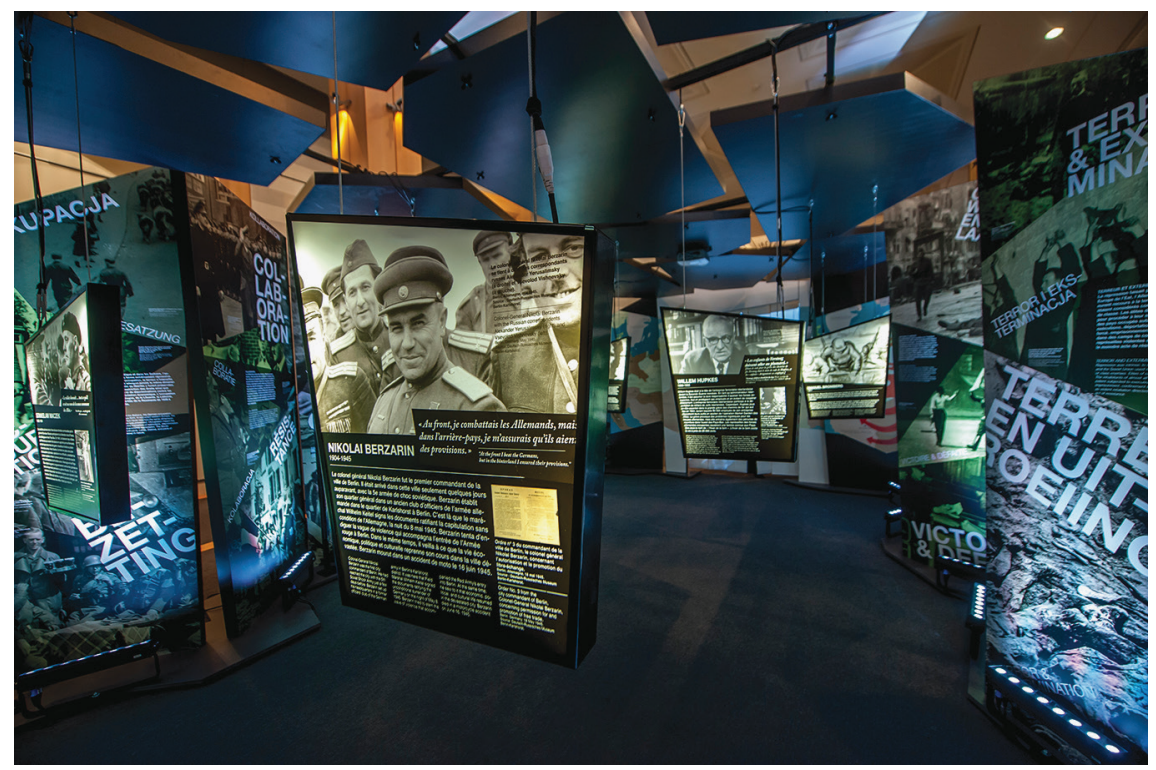

FIGURE 3 The core of the exhibition with the themes to the sides and biographies in the middle. (c) Stichting Liberation Route Europe.

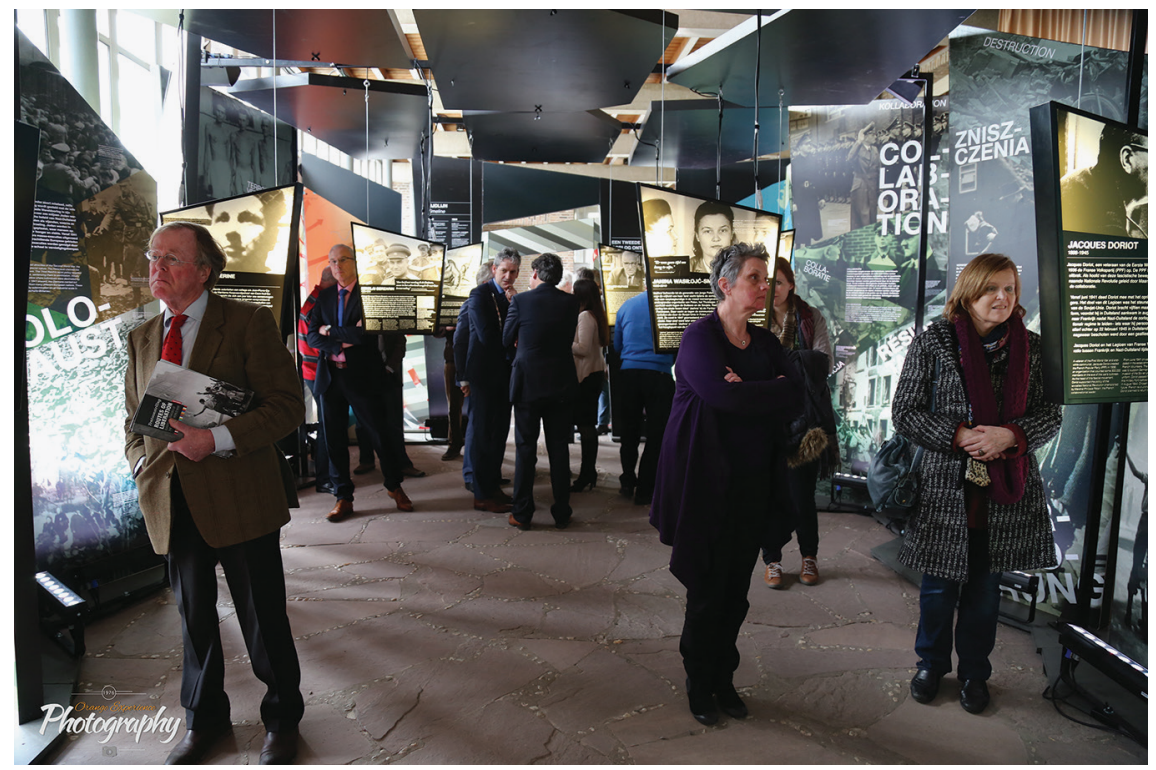

FIGURE 4 Visitors in the Routes of Liberation exhibition. (C) Liberation Route Europe Foundation/ Picspoint. 


\section{Bibliography}

Bessel, Richard. 2009. Germany 1945 From War to Peace. London, Harper Perennial.

Ginkel, van Rob. 2011 . Rondom de Stilte. Herdenkingscultuur in Nederland. Amsterdam, Prometheus.

Heyl, Matthias. 2009. "Duitse Herinneringscultuur: Gedachten en Patronen." In F. van Vree en R. van der Laarse, Dynamiek van de herinnering. Amsterdam, Uitgeverij Bert Bakker. 22-244.

Heijden, van der Chris. 2001. Grijs verleden. Nederland en de Tweede Wereldoorlog. Amsterdam, Uitgeverij Contact.

Liberation Route Europe Foundation. 2015. Magna Carta. Unpublished manuscript.

Somers, Erik. 2014. De Oorlog in Het Museum. Herinneringen en Verbeelding. Zwolle, Uitgeverij Wbooks.

Vree, van Frank en Rob van der Laarse. 20og. Dynamiek van de Herinnering. Amsterdam, Uitgeverij Bert Bakker. 